\title{
Effect of Virus Input Multiplicity and Tissue Cell Concentration on Growth of Rift Valley Fever Virus
}

\author{
MICHAEL D. ORLANDO, RICHARD D. DELAUTER, AND JEAN M. RILEY \\ Department of the Army, Fort Detrick, Frederick, Maryland 21701
}

Received for publication 21 December 1966

\begin{abstract}
The effects of virus input multiplicity and of tissue cell concentration upon the growth of Rift Valley fever virus in L cells (Earle) were determined. The titers obtained in suspension cultures with cells obtained from two separate laboratories were significantly different. With both monolayer culture and suspension culture systems, a virus input multiplicity of 2.5 resulted in the greatest proliferation of virus. Optimal viral yields were obtained in suspension cultures containing $4 \times 10^{5}$ tissue cells per $\mathrm{ml}$ of suspension.
\end{abstract}

Although many papers have been presented on Rift Valley fever (RVF) virus since its isolation by Daubney, Hudson, and Garnham (3), the work reported on the growth of RVF virus in tissue culture systems has been meager. Easterday and Murphy (4) described the growth of RVF virus in five established cell lines under a limited set of conditions. Coackley (1) described the alteration in virulence that occurs during serial passage in lamb testis cells. Tribble and Boyle (unpublished data) studied the growth of RVF virus in L cells (Earle) in suspension cultures, of 30-ml volume, in Nagle's defined medium. However, the effects of virus input multiplicity (ratio of infectious inoculum to tissue cells) and tissue cell concentration were not reported.

This report describes the growth of RVF virus in $\mathbf{L}$ cells (Earle) obtained from two separate sources and the effect of virus input multiplicity and tissue cell concentration upon that growth.

\section{Materials AND Methods}

Virus strain. The pantropic Van Wyk strain of RVF virus described by Kashula (unpublished data) was used. Infected lamb serum stored at $-70 \mathrm{C}$ was the working seed stock. It had a titer of about $10^{8.3}$ mouse intracerebral median lethal doses (MICLD ${ }_{50}$ ) per $\mathrm{ml}$.

Tissue culture systems. The established L cell (Earle) line was obtained from two laboratories. In laboratory 1 , the cell line had been maintained in suspension cultures (2) in Eagle's minimum essential medium (double strength) with Earle's balanced salt solution supplemented with bovine serum $(10 \%)$, cysteine $(260 \mu \mathrm{g} / \mathrm{ml})$, and ascorbic acid $(50 \mu \mathrm{g} / \mathrm{ml})$. In laboratory 2 , the cell line had been maintained as monolayers in medium 199 (6) containing calf serum $(10 \%)$.
Cultures were maintained in our laboratory as either monolayers or suspension cultures at $36 \mathrm{C}$. The monolayer cultures were prepared in $650-\mathrm{ml}$ roller bottles (Strumia blood plasma bottles; Arthur Thomas Co., Philadelphia, $\mathrm{Pa}$.) rotated at $7 \mathrm{rev} / \mathrm{min}$. The total cell concentration in the average roller bottle was $2.8 \times$ $10^{7}$ cells with $80 \mathrm{ml}$ of growth medium. Suspension cultures were prepared in $100-\mathrm{ml}$ volumes in centrifuge bottles $(250-\mathrm{ml})$ fitted with Teflon-coated, suspended bar magnets and removable vents (Rosensteel and Daniels, personal communication). Medium 199 containing $10 \%$ calf serum was used as the growth medium. Penicillin (250 units/ml), dihydrostreptomycin $(250 \mu \mathrm{g} / \mathrm{ml})$, and kanamycin $(50 \mu \mathrm{g}$ ) $\mathrm{ml}$ ) were added to the growth medium only during the viral infectivity studies.

Infection of tissue cultures. The roller bottles and suspension cultures were infected with sufficient inoculum in a total volume of $10 \mathrm{ml}$ of growth medium to obtain virus input multiplicites of $1,2.5,5$, and 10 .

The suspension cultures were started with total cell populations of $20,40,80,120,160$, or 200 million cells. The amount of virus inoculum varied with the total cell population so that a constant virus input multiplicity of 2.5 was maintained.

The culture systems were incubated $36 \mathrm{C}$.

Assay. Ten-fold serial dilutions were made in medium 199 containing $10 \%$ calf serum. Mice (SwissWebster, 10 to $14 \mathrm{~g}$ ) were injected intracerebrally with $0.03-\mathrm{ml}$ amounts of appropriate virus dilutions. Ten mice were injected per dilution, and deaths were recorded during the next 6 days. Deaths prior to 24 $\mathrm{hr}$ were assumed to be traumatic. The $\mathrm{LD}_{50}$ values were calculated by the method of Reed and Muench (6).

\section{RESULTS}

The results of the study (means of four replicates) on the effect of virus input multiplicity are presented in Table 1 . In the roller bottles (mono- 
TABLE 1 Effect of virus input multiplicity on the growth of Rift Valley fever virus

\begin{tabular}{|c|c|c|c|c|c|c|c|}
\hline \multirow{3}{*}{$\begin{array}{c}\text { Virus } \\
\text { input } \\
\text { multiplic- } \\
\text { ity }\end{array}$} & \multicolumn{7}{|c|}{ Titer $($ MICLDso/ml) at various times $(\mathrm{hr})$} \\
\hline & \multicolumn{2}{|c|}{$\begin{array}{l}\text { Monolayer } \\
\text { cultures }^{a}\end{array}$} & \multicolumn{5}{|c|}{ Suspended cultures ${ }^{b}$} \\
\hline & 0 & 72 & 0 & 24 & 48 & 72 & 96 \\
\hline 1 & 6.00 & 7.60 & 6.60 & $-c$ & 6.44 & 6.30 & 5.34 \\
\hline 2.5 & 6.40 & 7.99 & 6.90 & 6.51 & 6.51 & 7.17 & 5.65 \\
\hline 5 & 6.70 & 7.65 & 7.20 & 7.50 & 6.80 & 6.74 & 5.82 \\
\hline 10 & 7.00 & 7.69 & 7.50 & 7.26 & 6.70 & 6.73 & 6.27 \\
\hline
\end{tabular}

a Results are the means of the titers obtained from cells secured from both laboratories (no significant difference between cell sources).

${ }^{b}$ Results are those obtained with cells secured from laboratory 2 only.

$c$ Samples lost.

TABLE 2. Effect of tissue cell concentration of suspension cultures on the growth of Rift Valley virus

\begin{tabular}{r|r|r|r|r|r|r}
\hline & & \multicolumn{4}{|c}{ Virus output factor } \\
\cline { 3 - 6 } $\begin{array}{c}\text { Cell concn } \\
\text { millions per } \\
\text { suspension) }\end{array}$ & Titer (MICLD50/ml) & \multicolumn{2}{|c|}{$\begin{array}{c}\text { Per tissue } \\
\text { culture cell }\end{array}$} & $\begin{array}{r}\text { Per viral LD50 } \\
\text { of inoculum }\end{array}$ \\
\cline { 2 - 7 } & $1^{a}$ & 2 & 1 & 2 & 1 & 2 \\
\hline 20 & 6.30 & 6.81 & 10 & 32 & 4 & 13 \\
40 & 6.87 & 7.45 & 19 & 70 & 8 & 28 \\
80 & 6.56 & 7.16 & 5 & 18 & 2 & 8 \\
120 & 6.31 & 7.42 & 2 & 22 & 1 & 13 \\
160 & 6.26 & 7.16 & 1 & 9 & $>1$ & 4 \\
200 & $-b$ & 7.16 & - & 7 & - & 3 \\
\hline
\end{tabular}

a Numbers 1 and 2 denote the two different laboratory sources of $\mathbf{L}$ cell (Earle) lines.

${ }^{b}$ Samples were gelatinous and could not be resuspended in diluent.

layer system), the effect of virus input multiplicity could readily be seen by comparing the virus output factors (yield titer divided by inoculum titer) as shown in the following: at an input multiplicity of either 1 or 2.5 , the output factor was 40 ; at an input of 5 , the output was 8 ; at an input of 10 , the output was 5 .

Judged by the virus output factors, the use of either the 1- or 2.5-virus input multiplicities produced the maximal growth ratios; however, based on the largest virus yield per unit volume $\left(\mathrm{MICLD}_{50} / \mathrm{ml}\right)$, the 2.5 -virus input multiplicity was optimal.

The results of the study on virus input multiplicities in suspension cultures were disappointing. Apparently, the only virus input multiplicity that resulted in a proliferation of the virus occurred with the 2.5 virus input dose after $72 \mathrm{hr}$ (an increase of only $0.27 \mathrm{log}$ ).

The results of the study (means of four replicates) on the effect of various tissue cell concentrations are summarized in Table 2; only the virus titers obtained after $72 \mathrm{hr}$ of incubation are presented. No significant differences in titers were observed when the cultures were prepared with cells secured from the same source. However, significant differences were observed when the cultures were prepared with cells secured from two different laboratories. Thus, at each cell concentration used, the virus titers obtained with the cells secured from laboratory 2 were significantly greater than the titers obtained with cells secured from laboratory 1 .

The effect of tissue cell concentration can be seen more readily by comparing the virus output factors. The optimal virus yield was obtained at a concentration of 40 million cells per $100 \mathrm{ml}(4 \times$ $10^{5} / \mathrm{ml}$ ) with cells originally obtained from laboratory 2 .

\section{Discussion}

Although the source of $\mathrm{L}$ cells (Earle) did not affect the growth or yield of RVF virus in monolayers, a significant effect was seen in the suspension cultures. With either the monolayer or the suspension culture system, the optimal virus input multiplicity was apparently 2.5 . Although the difference in virus input multiplicity varied 10 -fold, there was complete destruction of the tissue cells by $72 \mathrm{hr}$ in the monolayer cultures.

The optimal cell concentration in the suspension culture system is apparently $40 \times 10^{6}$ cells per $100 \mathrm{ml}\left(4 \times 10^{5} / \mathrm{ml}\right)$. Many factors may influence proliferation of the virus. Since the suspension culture system was not designed with precise controls, the reasons for optimal growth at this cell concentration cannot be specified. If the suspension culture study had been conducted in a "controlled" manner as described by Daniels et al. (2), a better understanding of the metabolic effects of viral infection could probably have been reached. Since cytolytic viruses alter the biosynthetic processes of the tissue cells, one could then study the biochemical changes that occur in the RVF virus-tissue cell infection.

\section{Literature Cited}

1. Coackley, W. 1965. Alteration in virulence of Rift Valley fever virus during serial passage in lamb testis cells. J. Pathol. Bacteriol. 89:123131.

2. Daniels, W. F., D. A. Parker, R. W. Johnson, AND L. E. SCHNEIDER. 1965. Controlled pH and oxidation-reduction potential with a new glass tissue culture fermentor. Biotechnol. Bioeng. 7:529-553.

3. Daubney, R., J. R. Hudson, and P. C. Garn- 
HAM. 1931. Enzootic hepatitis or Rift Valley fever, an undescribed virus disease of sheep, cattle and man from East Africa. J. Pathol. Bacteriol. 34:545-579.

4. Easterday, R. C., AND L. C. Murphy. 1963. The growth of Rift Valley fever virus in cultures of established lines of cells. Cornell Vet. 58:3-11.
5. Morgan, J. F., H. J. Morton, and R. C. Parker. 1950. Nutrition of animal cells in tissue cultture. I. Studies on synthetic medium. Proc. Soc. Exptl. Biol. Med. 73:1-15.

6. REED, L. J., AND H. MUenCh. 1938. A simple method of estimating fifty per cent end-points. Am. J. Hyg. 27:493-497. 